\title{
Effect of Partial Substitution of a Commercial Feed Crude Protein by Hydroponic Barley Fodder in Diets of Apri rabbits on: 1- Digestibility, Feeding Value, some Blood Constituents and Caecum Microflora Count
}

\author{
Mehrez, A. Z.; A. A. Gabr; M. Y. El-Ayek and Alaa M. Gad
}

Animal Prod. Dept., Fac. of Agric., Mansoura Univ., Egypt.

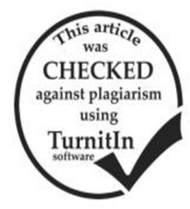

\section{ABSTRACT}

Fourty growing APRI male rabbits at the age of 5 weeks old were used to investigate the impact of partial replacement of concentrate feed mixture (CFM) CP by different levels of hydroponic barley (HB) on rabbits performance, digestibility, feeding value, some blood constituents and caecum microbial count. The changes in chemical composition of HB during 6,7 and 8 days of growth period was also studied. Rabbits were randomly divided into four experimental groups (10 rabbits in each) and were housed in individual cages provided with continuous feeders and automatic water nipples during the experimental period ( $5-12$ week of age). The first group was fed pelleted CFM diet with $16 \%$ CP (control, D1), while the $2^{\text {nd }}, 3^{\text {rd }}$ and $4^{\text {th }}$ groups were fed the control diet but 20,40 and $60 \%$ of CP was replaced by HB (D2, D3 and D4, respectively) in a feeding trial which lasted for 7 weeks. At the end of the feeding trial, four digestibility trials were carried out on three rabbits of each treatment. Animals were fed the same tested diet as that in feeding trial. Three rabbits of each treatment were slaughtered at the end of digestibility trials. The main results generally showed that there was a tendency for gradual decreases in DM and NFE content, but increases in Ash, EE, CP and CF content by advancing age of sprouting. Rabbits fed $\mathrm{D} 2$ recorded the highest significantly $(\mathrm{P}<0.05)$ values of digestion coefficients of $\mathrm{CP}$ and $\mathrm{CF}$, while the lowest significantly $(\mathrm{P}<0.05)$ values were recorded with rabbits fed $\mathrm{D} 4$ diet. There were positive significant $(\mathrm{P}<0.05)$ effect of feeding $\mathrm{HB}$ at levels of 20 and $40 \%$ on concentrations of blood total protein, albumin and glucose. Rabbits fed HB diets (D2, D3 and D4) had significantly $(\mathrm{P}<0.05)$ higher total viable count of bacteria in caecum compared with those fed the control diet without HB (D1). It may be concluded that replacing of $\mathrm{HB}$ at the rate of 20 or $40 \%$ of CFM protein in growing rabbit diets had beneficial effects on most criteria studied. Higher level $(60 \%$ of HB) used herein in rabbit diets is not recommended since it negatively affected nutrients digestibility and feeding values of tested diets. Keywords: rabbits, hydroponic barley, digestibility, nutritive value, blood constitues.

\section{INTRODUCTION}

In animal production enterprises, fodder production is the most important input in livestock ration and has important aspects for the sustainability of products and productivity in animal husbandry (Gupta, 2014). Feeding animals according to their requirements and avoiding wastage is the basic point in exploiting the production potential for economic growth and sustainability since feed costs are the dominant part of production that accounts more than $70 \%$ (Gupta, 2014). It is a well-accepted fact that feeding animals is incomplete without including green fodder in their diet (Shah et al., 2011). Due to the lot of constraints in the conventional method of green fodder cultivation in most of the Middle East, African and Asian countries, hydroponics is now emerging as an alternative technology to grow fodder for farm animals (Sneath and Mclntosh 2003, Naik et al. 2011, 2012 and 2013). Thus, fodder is produced without using any soil but growing the plants in water or mineral nutrient solution is known as hydroponics fodder or fresh fodder biscuits or sprouted grains or sprouted fodder or alfa culture (Dung et al., 2010 and Bakshi et al., 2017). The advantages of this method include: growing crops in a hygienic environment free of chemicals, and artificial growth promoters (Jensen and Malter, 1995). Hydroponic fodder has a short growth period (around 7-10 days) and requires a small piece of land for production (Mooney, 2005). In recent years, it has been a major vacancy for researchers to study the animals performance and lower feeding costs. Therefore, there are an increased interests in studying feed restriction in rabbits, which it is an excellent source of good quality meat compared with conventional sources of meat, such as beef cattle, goats and sheep (Shanti et al., 2017). Research on availability of hydroponic grown forage as livestock feed, especially in rabbits is very limited needing more research to help determine their optimal level in their diets. Therefore, this study aimed to investigate the influence of feeding different levels of dietary hydroponic barley in tested diets on digestion coefficients, feeding value, some blood constituents and caecum microbial count of APTI growing rabbits.

\section{MATERIALS AND METHODS}

The present study was conducted in a private Rabbit Farm at Mansoura city of Al-Dakahlia, Egypt, during the period from March to April, 2017.

Hydroponic System and Grain Sprouting: Hydroponic barley was sprouted in a temperature controlled room at the same farm. The temperature was maintained at $24^{\circ} \mathrm{C}$ and continuous lighting was also provided throughout the 7days growing period. Spray watering was applied for 3 minutes every 2 hours for the 7 days period of growing. A sprinkler with a timer control device was used to achieve the set interval and running time indicated above. The excess water drained freely from the growing trays between watering. Three pairs of fluorescent lamps of (Philips TLD 36W/840) were used. An air conditioner was used to control temperature inside the growth chamber which was maintained at $24^{\circ} \mathrm{C} \pm 1^{\circ} \mathrm{C}$. The relative humidity in the growth room was $54 \%$.

Three growth periods: Barely (Hordeum vulgare L.) cv. Giza 123 grains were used. The grains were obtained from the Agriculture Research Center Ministry of Agriculture, Gamisa, Egypt and hydroponically grown up to 6, 7 and 8 days. The trays contained green fodder were removed from the chamber and the fresh fodder batches were weighed and sampled to measure the exchange in chemical composition through different growth period $(6,7$ and 8 days of age). Representative samples (250 g each), were oven-dried at $60^{\circ} \mathrm{C}$, ground to pass a $1-\mathrm{mm}$ mesh screen sieve and stored for chemical analysis.

Digestibility trails: Forty male APRI newly weaned rabbits at 5 week old of similar body weight, were randomly distributed into four experimental groups (10 rabbits in each) for a growth trail which lasted for 5-12 week of age. The data obtained for $2^{\text {nd }}$ part of the present study concerning the impact of tested diets on rabbit's performance will be 
published later on. At the end of feeding trials, twelve male APRI rabbits were chosen from the previous herd and individually housed in cages and fed the same dietary treatments. Four digestibility trials (3 rabbits in each) were carried out to determine the digestibility of nutrients and nutritive values of the following experimental diets: group one (D1) was fed the control diet (concentrate feed mixture (CFM), groups 2, 3 and 4 were fed the control diet after replacing CFM-CP with 20, 40 and $60 \%$ of hydroponic barley (HB-CP) and will be referred to as D2, D3 and D4, respectively. All diets covered the daily $\mathrm{CP}$ requirements of rabbits according to NRC (1977) and Cheeke (1987). The formulation of the pelleted basal diet is presented in Table (1). The CFM meal was offered at the morning while that of hydroponic barley fodder was given at the evening. Fresh water was provided all the time. Individual feed intake was accurately determined and quantitative collection of feces was carried out for 5 days as a collection period and feces of each animal was mixed. Samples of $\mathrm{HB}$ and feces were dried at $60^{\circ} \mathrm{C}$ for 48 hours, and ground for running the chemical analysis. Chemical analysis of HB, CFM, barley grains (BG) and feces was determined using the official methods of analysis (AOAC, 2000) procedures. Apparent digestibility of nutrients as well as the nutritive values as TDN, DCP and DE were calculated for the different dietary tested diets. Chemical analysis was done at the laboratory of Anim. Prod. Dept., Fac. of Agric. at Mansoura Univ., Egypt. The total digestible nutrients (TDN) were calculated according to the formula of Cheeke et al. (1982), while the digestible energy (DE, $\mathrm{Kcal} / \mathrm{Kg}$ ) of diets was estimated according to the equation adopted by Schiemane et al. (1972) as follows: DE, $\mathrm{Kcal} / \mathrm{Kg} \mathrm{DM}=5.28$ (DCP, g/Kg + 9.51 (DEE g/Kg) + $4.2(\mathrm{DCF} \mathrm{g} / \mathrm{Kg})+4.2(\mathrm{DNE} \mathrm{g} / \mathrm{Kg})$.

Blood parameters: After running the digestion trials, the 3 rabbits of each treatment which used before were fasted and slaughtered. A blood sample from each rabbit was collected to determine some blood metabolites. The blood samples were collected in heparinized tubes. Blood samples were immediately centrifuged at 3000 r.p.m for 15 minutes in order to separate blood plasma. Plasma samples were frozen at $-20^{\circ} \mathrm{C}$ to be used for biochemical analysis. Commercial Kits were used for colorimetric determinations of: Glucose, Total protein (TP), Albumin (AL), Triglycerides, Cholesterol, Aspartic aminotransferase (AST) and Alanine amino transferase (ALT). The globulin value (GL) was calculated by differences (TP-AL).

Caecum microbial count: Microbial total count of the caecum from 3 rabbits/treatment after slaughtering were calculated by using swab method and cecum length of each rabbit was measured.

Statistical analysis: Data of the present study were statistically examined using complete randomized design according to SAS (2003). Dunkan's Multiple Range Test (Duncan, 1955) was performed to detect the significant differences among means. According to the following model:

\section{Where:}

$$
\mathbf{Y i j}=\boldsymbol{\mu}+\mathbf{T i}+\mathbf{e i j}
$$

Yij $=$ The individual observation

$\mu$ is the overall mean

Ti is the treatment type (D1, D2, D3 and D4)

eij is the random error term
Table 1. Formulation of the pelleted basal diet (control diet).

\begin{tabular}{lccc}
\hline $\begin{array}{l}\text { Ingredients } \\
\text { \% }\end{array}$ & $\begin{array}{c}\text { Control } \\
\text { diet }\end{array}$ & $\begin{array}{c}\text { Ingredients } \\
\%\end{array}$ & $\begin{array}{c}\text { Control } \\
\text { diet }\end{array}$ \\
\hline Wheat bran & 22.00 & Limestone & 1.00 \\
Soy bean meal $(44 \%)$ & 20.00 & Common salt & 0.30 \\
Alfa alfa & 20.00 & $\begin{array}{c}\text { Vit. \& Min. Premix } \\
\text { \$ }\end{array}$ & 0.30 \\
Caraway straw & 15.00 & $\begin{array}{c}\text { Di calcium } \\
\text { phosphate }\end{array}$ & 1.25 \\
Yellow corn & 5.00 & Anti-toxin & 0.10 \\
Barley grains & 15.00 & Anti - coccidian & 0.05 \\
\hline Total & & 100 &
\end{tabular}

\$: Each $3 \mathrm{~kg}$ of the product contains:Vit. A, 12,000,000 IU; Vit. $\mathrm{D}_{3}$, 2,500,000 IU; Vit. E, $10 \mathrm{~g}$; Vit. K, $2.5 \mathrm{~g}$; Vit. $B_{6} 1.5 \mathrm{~g}$; Vit. $B_{12}, 10 \mathrm{mg}$; Biotin, $50 \mathrm{mg}$; Folic acid, $1.0 \mathrm{~g}$; Nicotinic acid, $30 \mathrm{mg}$; Pantothenic acid, 10 g; Antioxidant, 19 g; Mn, 60 g; Cu, 10 g; Zn, 55 g; Fe, 35 g; I, $1.0 \mathrm{~g} ; \mathrm{Co}, 250 \mathrm{mg}$ and $\mathrm{Se}, 150 \mathrm{mg}$

\section{RESULTS AND DISCUSSION}

Chemical composition of barley grains (BG) and hydroponic barley fodder during the last three days $(6,7$ and 8 of age) of growing period by hydroponic system:

As shown in Table (2), OM content was practically similar for the three days, while the CP contents in $\mathrm{HB}$ at 6 , 7 and 8 of age were higher by about $2.5,3.3$ and $3 \%$ compared with BG. Likewise, EE, CF, ADF and NDF in $\mathrm{HB}$ during the last three days were higher than those of $\mathrm{BG}$. In contrary, NFE and hemicellulose contents tended to be higher in $\mathrm{BG}$ than the corresponding values of $\mathrm{HB}$ during the three days of growing. As for DE concentration, it was considerably higher in $\mathrm{BG}(3609 \mathrm{Kcal} / \mathrm{Kg})$ than those recorded for $\mathrm{HB}$ at 6, 7 and 8 days of age, being 3192, 3212 and $3221 \mathrm{Kcal} / \mathrm{Kg}$, respectively. Regarding the effect of growing period on changes in chemical composition of $\mathrm{HB}$, the results generally showed that there was a tendency for gradual decreases in DM and NFE, but increases in ash, EE, $\mathrm{CP}$ and $\mathrm{CF}$ contents by advancing age of plants. However, the OM content was practically similar for the samples taken during the three days of growing. Likewise, there were small differences in ADF, NDF and hemicellulose contents among different samples for HB during three days. Generally, it is worth noting that the chemical composition values of $\mathrm{HB}$ at 7 days was practically similar with those recorded with $\mathrm{HB}$ at 8 days since small differences were observed among them in most chemical nutrients. So, HB at 7 days have been chosen to be fed in the applied feeding trials with growing rabbits. The lower DM \% of HB may be due to that the large uptake of water initiates increases metabolic activity of resting seeds leading to loss of dry weight (starch) during germinating cycles of hydroponic fodder (Morsy et al., 2013). The increase in EE content could be due to the production of chlorophyll associated with plant growth that are recovered in ether extract measurement (Mayer and Poljakoff-Mayber, 1975). Such changes in nutrients profile and recovery are misleading, since they only described the alterations in the proportion of nutrients during growth and sprouting of seeds (Morgan et al. 1992). A change in weight of any one of the nutrient led to proportional changes in other compositions. During the germination and early stage of plant growing, starch was catabolized to soluble sugars for use in respiration and cell-wall synthesis (Hillier and Perry, 1969). In addition, the CP content could be affected by the cultivation conditions in hydroponic systems. 
Hydroponic system alters the amino acid profile of BG and increases the crude protein content of hydroponic barley (Morsy et al., 2013). The increase in CF content during hydroponic system of barley may be due to the synthesis of structural carbohydrates such as cellulose, hemicelluloses and lignin (Cuddeford, 1989).

Table 2. Chemical composition of the barley grain (BG) and hydroponic barley (HB) during the last three days (6, 7 and 8 of age) of growing by hydroponic system (\% DM).

\begin{tabular}{|c|c|c|c|c|}
\hline \multirow{2}{*}{ Items } & \multirow{2}{*}{$\begin{array}{l}\text { Barley } \\
\text { grains }\end{array}$} & \multicolumn{3}{|c|}{ Hydroponic barley } \\
\hline & & $6^{\text {th }} d$ & $7^{\text {th }} \mathrm{d}$ & $8^{\text {th }} d$ \\
\hline$\overline{\mathrm{DM}}$ & 93.1 & 17.39 & 15.0 & 12.59 \\
\hline \multicolumn{5}{|c|}{$\%$ of DM basis } \\
\hline $\mathrm{OM}$ & 97.6 & 96.9 & 96.3 & 96.1 \\
\hline $\mathrm{EE}$ & 1.8 & 2.13 & 3.1 & 4.8 \\
\hline $\mathrm{CP}$ & 12.7 & 15.2 & 16.0 & 15.7 \\
\hline $\mathrm{CF}$ & 6.3 & 14.1 & 14.5 & 16.0 \\
\hline NFE & 76.8 & 65.5 & 62.7 & 59.6 \\
\hline Ash & 2.4 & 3.1 & 3.7 & 3.9 \\
\hline \multicolumn{5}{|c|}{ *Fiber fractions } \\
\hline $\mathrm{NDF}$ & 33.1 & 38.2 & 38.5 & 39.4 \\
\hline $\mathrm{ADF}$ & 15.2 & 22.3 & 22.7 & 24.0 \\
\hline Hemi-cellulose & 17.9 & 15.9 & 15.8 & 15.4 \\
\hline **DE (Kcal/ kg) & 3609 & 3192 & 3212 & 3221 \\
\hline
\end{tabular}

* Fiber fraction (NDF and ADF \%) calculated according to Pagano Toscano et al. (1986) using the following equation:

$\% \mathrm{ADF}=9.432+0.912(\% \mathrm{CF})$

$\% \mathrm{NDF}=28.924+\mathbf{0 . 6 5 7}(\% \mathrm{CF})$

$\%$ Hemi-cellulose = \% NDF - \% ADF

* *Digestible energy (DE) calculated according to Fekete (1987) using the following equation:

$\mathrm{DE}(\mathrm{Kcal} / \mathrm{kg})=(7.1(\mathrm{CP}, \mathrm{g} / \mathrm{kg}))+(12(\mathrm{EE}, \mathrm{g} / \mathrm{kg}))+(5.59(\mathrm{NFE}, \mathrm{g} / \mathrm{kg}))$

Chemical analysis of ingredients and calculated composition of the tested diets:

Data in Table (3) showed that the chemical composition of concentrate feed mixture (CFM) and hydroponic barley (HB) was within the normal published ranges in Egypt given by Abouelezz and Hussein (2017) and Raeisi et al. (2018). Regarding the calculated chemical composition of tested diets, it is showed that tested diets are nearly similar in EE, CP, CF, NDF and hemi-cellulose contents. It is evidence that DM and Ash content of tested diets tended to decreased gradually with increasing the level of HB. On the other hand, OM, NFE and $\mathrm{ADF}$ content of tested diets tended to increased gradually by increasing the level of $\mathrm{HB}$ being the highest in D4 (88.6, 56.7 and $21.4 \%$, respectively) and the lowest in D1 ( 85.2, 54.0 and $20.7 \%$, respectively).

The DE concentration of tested diets was gradually increased by increasing the level of HB level, being 2690, 2762, 2790 and $2841 \mathrm{Kcl} / \mathrm{kg}$ for D1, D2, D3 and D4 diets, respectively.

Effect of feeding HB on nutrients digestibility and feeding values:

Data in Table (4) cleared that DM, OM, EE and NFE digestibilities were significantly $(\mathrm{P}<0.05)$ highest in rabbits fed D1 (without $\mathrm{HB}$ ) compared with those fed different levels of HB diets (D2, D3 and D4). The obtained values of $\mathrm{CP}$ digestibility showed that group fed D2 was significantly $(\mathrm{P}<0.05)$ the highest value $(78.62 \%)$ compared with those fed D3 and D1 (76.06 and 75.16\%, respectively) without significant difference between the latter diets. While, the lowest $\mathrm{CP}$ value was observed with group fed D4 $(59.42 \%)$. Digestibility coefficient of CF was significantly $(\mathrm{P}<0.05)$ the highest with rabbits fed $\mathrm{D} 2$ $(42.53 \%)$, while, the lowest value was recorded with group fed D4 (25.74 \%).

Table 3. Proximate chemical analysis (\%), calculated gross energy (GE) $(\mathrm{Mj} / \mathrm{kg} \mathrm{DM})$, digestible energy (DE) (Kcal/Kg) of tested feed ingredients and the calculated composition of the tested diets (on DM \% basis).

\begin{tabular}{|c|c|c|c|c|}
\hline \multirow{2}{*}{ Item } & \multicolumn{4}{|c|}{ Feed ingredients } \\
\hline & \multicolumn{2}{|c|}{ HB } & \multicolumn{2}{|c|}{ CFM } \\
\hline$\overline{\mathrm{DM}}$ & \multicolumn{2}{|c|}{15.0} & \multicolumn{2}{|c|}{91.3} \\
\hline $\mathrm{OM}$ & \multicolumn{2}{|c|}{96.3} & \multicolumn{2}{|c|}{85.1} \\
\hline $\mathrm{EE}$ & \multicolumn{2}{|c|}{3.04} & \multicolumn{2}{|c|}{2.77} \\
\hline $\mathrm{CP}$ & \multicolumn{2}{|c|}{16.0} & \multicolumn{2}{|c|}{16.0} \\
\hline $\mathrm{CF}$ & \multicolumn{2}{|c|}{14.5} & \multicolumn{2}{|c|}{12.4} \\
\hline NFE & \multicolumn{2}{|c|}{62.8} & \multicolumn{2}{|c|}{53.9} \\
\hline Ash & \multicolumn{2}{|c|}{3.7} & \multicolumn{2}{|c|}{14.9} \\
\hline \multicolumn{5}{|c|}{ Experimental diets } \\
\hline Item & D1 & D2 & D3 & D4 \\
\hline$\overline{\mathrm{DM}}$ & 91.3 & 82.0 & 75.4 & 67.3 \\
\hline $\mathrm{OM}$ & 85.2 & 86.5 & 87.4 & 88.6 \\
\hline $\mathrm{EE}$ & 2.8 & 2.8 & 2.8 & 2.8 \\
\hline $\mathrm{CP}$ & 16.0 & 16.0 & 16.0 & 16.0 \\
\hline $\mathrm{CF}$ & 12.4 & 12.4 & 12.8 & 13.1 \\
\hline NFE & 53.9 & 55.3 & 55.8 & 56.7 \\
\hline Ash & 14.9 & 13.5 & 12.6 & 11.4 \\
\hline \multicolumn{5}{|c|}{ *Fiber fraction } \\
\hline $\mathrm{NDF}$ & 37.1 & 37.1 & 37.2 & 37.5 \\
\hline $\mathrm{ADF}$ & 20.7 & 20.7 & 20.9 & 21.4 \\
\hline Hemi-celulose & 16.4 & 16.4 & 16.3 & 16.1 \\
\hline$* * \mathrm{DE}(\mathrm{Kcal} / \mathrm{kg})$ & 2690 & 2762 & 2790 & 2841 \\
\hline$* * * \mathrm{GE}(\mathrm{Mj} / \mathrm{kg} \mathrm{DM})$ & 16.8 & 17.5 & 17.3 & 17.5 \\
\hline
\end{tabular}

D1 (control), D2: C+20\% HB, D3: C+40\% HB and D4: C + 60\% HB

*Fiber fraction (NDF and ADF \%) calculated according to Pagano Toscano et al. (1986) using the following equation:

$\%$ ADF $=9.432+0.912(\%$ CF $) \quad \%$ NDF $=28.924+0.657(\%$ CF $)$ $\%$ Hemi-cellulose = \% NDF - \% ADF

**Digestable energy (DE) calculated according to Fekete (1987) using the following equation:

$\mathrm{DE}(\mathrm{Kcal} / \mathrm{kg})=(7.1(\mathrm{CP}, \mathrm{g} / \mathrm{kg}))+(12(\mathrm{EE}, \mathrm{g} / \mathrm{kg}))+(5.59(\mathrm{NFE}, \mathrm{g} / \mathrm{kg}))$

$* * *$ Gross energy (GE) calculated according to MAFF (1975) using the following equation:

GE $(\mathrm{Mj} / \mathrm{kg} \mathrm{DM})=0.0266 \mathrm{CP} \%+0.0407 \mathrm{EE} \%+0.0192 \mathrm{CF} \%+$ 0.0177 NFE\%

Similar results were reported by AL-Saadi and AlZubiadi (2015) who found that digestibility coefficient of CP and EE were significantly $(\mathrm{P}<0.05)$ higher in $30 \%$ sprouts supplementation group than $10 \%$ sprouts supplementation group and control group, respectively by Awassi male lambs. In this respect, Reddy et al. (1988) with cattle observed significant increase in the digestibility (\%) of all nutrients of diets containing hydroponic maize fodder (HMF) compared with the control diet. The latter authors explained such improvement in digestibility may be attributed to the tenderness of the fodder due to its lower age.

Shipard (2005) showed that sprouts are the most enzyme rich food on the plant and the period of greatest enzyme activity in sprouts is generally between germination and 7 days of age (Chavan et al., 1989).

As for the nutritive value of tested diets, it was clear that group fed control (D1) and (D2) diets had the highest significant $(\mathrm{P}<0.05)$ TDN values $(64.91$ and $63.30 \%$, 
respectively) without significant difference between them, then D3 (55. $22 \%)$. The lowest significant $(\mathrm{P}<0.05)$ value $(45.11 \%)$ was recorded with $\mathrm{D} 4$, which could be associated with lowest nutrients digestibility coefficients (Table 4). In the same trend, DE (Kcal / Kg) values were gradually decreased $(\mathrm{P}<0.05)$ with the increasing $\mathrm{HB}$ level where the best value was recorded for group of rabbits fed control diet (without HB, D1) $(2864.7 \mathrm{Kcal} /$ $\mathrm{Kg})$, followed by group fed D2 $(2763.1 \mathrm{Kcal} / \mathrm{Kg})$ without significant difference between them, while the lowest value was recorded with rabbits fed $60 \%$ HB (D4) (1998.4 Kcal / Kg), while group fed D3 showed intermediated value (2451.8 Kcal / Kg). As for DCP \%, rabbits received D2 and D3 diets recorded the highest significant $(\mathrm{P}<0.05)$ values of DCP (12.44 and $12.17 \%$,) than the control and those fed on D4 diet. While, the lowest significant $(\mathrm{P}<$ $0.05)$ value $(9.51 \%)$ of DCP \% was recorded with D4. These results are in good agreement with those obtained by Fayed (2011) with lambs in Sinai, who found that DCP values were significantly $(\mathrm{P}<0.05)$ higher with sprouted barley on Tamarix than untreated rice straw and tamarix. Similar trend was obtained by Ibrahim et al. (2001). There is a contradiction for the real effect of $\mathrm{HB}$ on nutrients digestibility that may be related to the composition of the tested diets, the percentage and variety of $\mathrm{HB}$ added to the diet, method of germination (hydroponic vs sprouted), the type of the animal used (monogastric vs ruminants), plan of nutrition and other environmental factors.

Table 4. Effect of feeding HB on digestion coefficients and feeding values of the tested diets with APRI rabbits.

\begin{tabular}{|c|c|c|c|c|c|}
\hline \multirow{2}{*}{ Item } & \multicolumn{4}{|c|}{ Experimental diets } & \multirow{2}{*}{ \pm SEM } \\
\hline & D1 & D2 & D3 & D4 & \\
\hline \multicolumn{6}{|c|}{ Digestibility coefficients\% } \\
\hline DM & $70.31^{\mathrm{a}}$ & $64.98^{\mathrm{b}}$ & $55.28^{\mathrm{c}}$ & $43.50^{\mathrm{d}}$ & 1.27 \\
\hline $\mathrm{OM}$ & $73.26^{\mathrm{a}}$ & $69.92^{b}$ & $59.73^{\mathrm{c}}$ & $47.26^{\mathrm{d}}$ & 1.24 \\
\hline EE & $83.53^{\mathrm{a}}$ & $80.28^{\mathrm{b}}$ & $78.19^{\mathrm{c}}$ & $69.28^{\mathrm{d}}$ & 0.22 \\
\hline $\mathrm{CP}$ & $75.16^{\mathrm{b}}$ & $78.62^{\mathrm{a}}$ & $76.06^{\mathrm{b}}$ & $59.42^{\mathrm{c}}$ & 0.50 \\
\hline $\mathrm{CF}$ & $40.34^{\mathrm{b}}$ & $42.53^{\mathrm{a}}$ & $35.67^{\mathrm{c}}$ & $25.74^{\mathrm{d}}$ & 0.31 \\
\hline NFE & $78.95^{\mathrm{a}}$ & $71.77^{\mathrm{b}}$ & $60.11^{\mathrm{c}}$ & $49.03^{\mathrm{d}}$ & 1.50 \\
\hline \multicolumn{6}{|c|}{ Nutritive values (on DM basis) $\%$} \\
\hline${ }^{*} \mathrm{TDN} \%$ & $64.91^{\mathrm{a}}$ & $63.30^{\mathrm{a}}$ & $55.22^{\mathrm{b}}$ & $45.11^{\mathrm{c}}$ & 0.93 \\
\hline $\mathrm{DCP} \%$ & $12.08^{\mathrm{b}}$ & $12.44^{\mathrm{a}}$ & $12.17^{\mathrm{ab}}$ & $9.51^{\mathrm{c}}$ & 0.08 \\
\hline $\mathrm{DE}(\mathrm{Kcal} / \mathrm{Kg})$ & $2864.7^{\mathrm{a}}$ & $2763.1^{\mathrm{a}}$ & $2451.8^{\mathrm{b}}$ & $1998.4^{\mathrm{c}}$ & 33.70 \\
\hline
\end{tabular}

D1 (control), D2: C + 20\% HB, D3: C + 40\% HB and D4: C + 60\% HB

*TDN\% was calculated according to classic formula (Cheeke et al., 1982) as follows:

$\% \mathrm{TDN}=\mathrm{DCP}+\mathrm{DCF}+\mathrm{DNF}+(\mathrm{DEE} * 2.25)$

DE was calculated according to Schiemane et al. (1972) as follows:

$\mathrm{DE}, \mathrm{Kcal} / \mathrm{Kg} \mathrm{DM}=5.28(\mathrm{DCP}, \mathrm{g} / \mathrm{Kg}+9.51(\mathrm{DEE} \mathrm{g} / \mathrm{Kg})+4.2(\mathrm{DCF}$ $\mathrm{g} / \mathrm{Kg})+4.2$ (DNFE g/Kg)

\section{Blood plasma constituents:}

The results in Table (5) revealed significant $(\mathrm{P}<0.05)$

effect of feeding $\mathrm{HB}$ at levels of 20 and $40 \%$ on concentrations of total protein, albumin and glucose. While, there were no significant differences among groups on concentration of globulin, cholesterol, triglycerides, urea and creatine concentrations. AST activity in blood plasma was significantly $(\mathrm{P}<0.05)$ decreased by using $20 \%$ and $40 \%$ of HB compared with rabbits fed diet D1 (without $\mathrm{HB}$ ) and D4 (60\% HB). Rabbits fed D4 showed lowest values of TP, Al and glucose, as well as the highest value of cholesterol, triglycerides, urea and creatine concentrations and AST activity. The increase of total protein and albumin concentration as affected by feeding HB may be associated with the high DCP content in D2 and D3 diets (Table 4), compared with the control (D1) diet. This is in accordance with those reported by Kumar et al. (1980) who found a positive correlation between dietary protein and plasma protein concentration by buffaloes. Also, Chavan et al. (1989) stated that the complex qualitative changes via soaking and sprouting of seeds which convert stored proteins of cereal grains into albumins and globulins caused the improvement of the quality of cereal proteins and increased the plant enzymes contents (Shipard, 2005). Through germination, protease enzymes are activated and convert the protein polymers into amino acids and small peptides (Shewry, 2007). These enzymes convert the complex compounds of protein into albumin and globulin which improve protein quality and elevate lysine content of grains (Chavan et al. 1989). Usually, biochemical blood parameters are reflected on health status and are good indicators of animal physiological, pathological, and nutritional status. In general, the obtained values of most plasma parameters were within the normal ranges given by Heinze (2002), being the normal ranges for total protein $(5.4-7.3 \mathrm{~g} / \mathrm{dl})$, albumin $(2.4$ - $4.5 \mathrm{~g} / \mathrm{dl})$, globulin $(2.9-4.9 \mathrm{~g} / \mathrm{dl})$, glucose $(80-150$ $\mathrm{mg} / \mathrm{dl})$, cholesterol $(10-80 \mathrm{mg} / \mathrm{dl})$, ALT $(10-45 \mathrm{IU} / \mathrm{l})$ and AST ( $10-120 \mathrm{IU} / \mathrm{l})$ for rabbits.

Table 5. Effect of feeding $\mathrm{HB}$ on some blood constituents of growing APRI rabbits fed experimental diets.

\begin{tabular}{|c|c|c|c|c|c|}
\hline \multirow{2}{*}{ Item } & \multicolumn{4}{|c|}{ Experimental diets } & \multirow[b]{2}{*}{ \pm SEM } \\
\hline & D1 & D2 & D3 & D4 & \\
\hline Total protein $(\mathrm{g} / \mathrm{dl})$ & $6.10^{\mathrm{ab}}$ & $6.87^{\mathrm{a}}$ & $6.40^{\mathrm{ab}}$ & $5.67^{b}$ & 0.28 \\
\hline Albumin (g/dl) & $3.07^{b}$ & $3.53^{\mathrm{a}}$ & $3.36^{\mathrm{ab}}$ & $2.97^{\mathrm{c}}$ & 0.11 \\
\hline Globulin (g/dl) & 3.03 & 3.33 & 3.04 & 2.70 & 0.28 \\
\hline Glucose (mg/dl) & 108.7 & 111.7 & 111.3 & 107.7 & 4.04 \\
\hline Cholesterol (mg/dl) & $56.3^{\mathrm{a}}$ & $46.3^{b}$ & $49.7^{\mathrm{ab}}$ & $57.0^{\mathrm{a}}$ & 2.36 \\
\hline Triglycerides $(\mathrm{mg} / \mathrm{dl})$ & $108.7^{\mathrm{a}}$ & $81.3^{\mathrm{c}}$ & $98.3^{\mathrm{b}}$ & $112.3^{\mathrm{a}}$ & 2.86 \\
\hline $\mathrm{LDL}(\mathrm{mg} / \mathrm{dl})$ & $44.3^{\mathrm{a}}$ & $33.7^{b}$ & $40.7^{\mathrm{a}}$ & $42.3^{\mathrm{a}}$ & 1.85 \\
\hline $\mathrm{HD}$ & $52.7^{\mathrm{b}}$ & $63.7^{\mathrm{a}}$ & $57.7^{\mathrm{b}}$ & $54.7^{\mathrm{b}}$ & 1.69 \\
\hline \multicolumn{6}{|c|}{ Kidney function } \\
\hline Urea & $39.7^{\mathrm{a}}$ & $27.7^{\mathrm{b}}$ & $34.7^{\mathrm{a}}$ & $40.0^{\mathrm{a}}$ & 1.80 \\
\hline rea & $1.41^{\mathrm{a}}$ & $1.06^{\mathrm{b}}$ & $1.36^{\mathrm{a}}$ & $1.43^{\mathrm{a}}$ & 0.05 \\
\hline \multicolumn{6}{|c|}{ Liver function } \\
\hline ALT & $31.0^{\mathrm{a}}$ & $21.0^{\mathrm{b}}$ & $26.0^{\mathrm{ab}}$ & $31.3^{\mathrm{a}}$ & 1.92 \\
\hline AST(IU/1) & $43.3^{\mathrm{a}}$ & $30.7^{\mathrm{b}}$ & $35.3^{\mathrm{b}}$ & $40.3^{\mathrm{a}}$ & 1.51 \\
\hline
\end{tabular}

D1 (control), D2: 20\% HB, D3: 40\% HB and D4: 60\% HB

$a \& b$ and $c .:$ means in the same row with different superscripts differ significantly $(\mathrm{P}<\mathbf{0 . 0 5})$

\section{Effect of dietary treatments on caecum total microbial counts (TMC):}

Results in Table (6) showed that rabbits fed HB diets (D2, D3 and D4) had significantly $(\mathrm{P}<0.05)$ increased the average total viable count of bacteria compared with those fed the control diet without HB (D1). Similar trend was obtained by El-Gogary et al. (2018) on rabbits. It is of great importance to note that replacing concentrate feed mixture (CFM) protein by HB significantly increase the total viable bacterial count, since $\mathrm{HB}$ has shown much improving positive effects on growth performance and controlling of pathogenic bacteria. In addition, one rabbit of group 4 fed $60 \%$ HB diet died, while no cases of death have been recorded with other treatments during the experimental 
period. In addition, about $55 \%$ and $20 \%$ of animals number in group D4 and D3 have suffered diarrhoeal illnesses at the age of 8 week and facultative among animals up to the end of experimental period. This could be associated with the high level of moisture in diets containing $\mathrm{HB}$ as well as could be a result of increasing pathogenic bacteria such as coliforms and especially $E$. coli which are important opportunist pathogens and can be a major cause of enteritis and losses in rabbits farm. Under some circumstances, pathogenic and toxigenic strains of the organism proliferate and cause diarrhea (Harcourt-Brown, 2002).

High percentage of diarrhoeal cases $(55 \%)$ as well as the death of one rabbit in group D4 could support this idea. However, more knowledge and information are needed to clarify the fractions of population of bacteria (beneficial or pathogenic bacteria) in cecum of rabbits fed $\mathrm{HB}$ diets to implement the intestinal health of rabbits (Bivolarski et al. 2011).

The length of cecum significantly $(\mathrm{P}<0.05)$ differed among tested groups. The significantly $(\mathrm{P}<0.05)$ highest cecum length was recorded with rabbits fed D3 and D4 (12.67 and $12.00 \mathrm{~cm}$, respectively), while the significantly $(\mathrm{P}<0.05)$ lowest value was observed with group fed D2 $(10.00 \mathrm{~cm})$.

Similarly, Abou Sekken et al. (2012) reveled that caecum length of rabbits was significantly $(\mathrm{P}<0.05)$ higher in all diets treated with sprouted grains than control.

Table 6. Effect of feeding $\mathrm{HB}$ diets on viable total bacterial count (cfu /g) in cecum of rabbits.

\begin{tabular}{lcc}
\hline Treatments & Cecum Length $(\mathbf{c m})$ & Total count $(\mathbf{c f u} / \mathbf{g})$ \\
\hline D1 & $11.50^{\mathrm{ab}}$ & $159^{*} 10^{3 \mathrm{~d}}$ \\
D2 & $10.00^{\mathrm{b}}$ & $219^{*} 10^{3 \mathrm{c}}$ \\
D3 & $12.67^{\mathrm{a}}$ & $266^{*} 10^{3 \mathrm{~b}}$ \\
D4 & $12.00^{\mathrm{a}}$ & $323^{*} 10^{3 \mathrm{a}}$ \\
\hline SEM & 0.546 & 18.33
\end{tabular}

D1 (control), D2: C+ 20\% HB, D3: C+ 40\% HB and D4: C+60\% HB a\& $b$ and $c$ : means in the same column with different superscripts differ significantly $(\mathbf{P}<\mathbf{0 . 0 5})$

\section{CONCLUSION}

It may be concluded that replacing of $\mathrm{HB}$ at the rate of 20 or $40 \%$ of CFM protein in growing rabbit diets had beneficial effect of most criteria studied. Higher level $60 \%$ replacing of $\mathrm{CFM}$ protein of $\mathrm{HB}$ used herein is not recommended since it negatively affected nutrients digestibility and feeding values of tested diets.

\section{REFERENCES}

Abou Sekken, M.S.M.; Taie, H.T. and Rabie, SH.A. (2012). Utilization of sprouted fenugreek and / or sprouted barley in rabbit feeding. Egyptian J. Nutrition and Feeds, 15 (2): 311-321.

Abouelezz, F.M.K. and Hussein, A.M.A. (2017). Evaluation of baker's yeast (saccharomyces cerevisiae) supplementation on the feeding value of hydroponic barley sprouts for growing rabbits. Egypt. Poult. Sci. Vol 37(III): 833-854.

Al-Saadi, M.J. and Al-Zubiadi, I.A.H. (2015). Effects of substitution barley by $10 \%, 30 \%$ of sprouted barley on rumen characters, digestibility and feed efficiency in diet of Awassi male lambs. International Journal of Science and Research (IJSR), 5 (4): 2228-2233.
AOAC (2000). Official Methods of Analysis. $17^{\text {th }}$ ed. Association of Official Analytical Chemists. Washington DC.

Bakshi, M.P.S.; Wadhwa, M. and Harinder, P.S. Makkar. (2017). Hydroponic fodder production: A critical assessment. Broadening.

Bivolarski, B.; Beev, G.; Denev, S.; Vachkova, E.; Kostadinova, G. and Slavov, T. (2011). Development of the caecal microbiota in rabbits weaned at different age. Agricultural Science and Technology, 3 (3): $212-219$.

Chavan, J.K.; Kadam, S.S. and Beuchat, L.R. (1989). Nutritional improvement of cereals by sprouting. Crit. Rev. Food Sci. Nutr., 28: 401-437.

Cheeke, P.R. (1987). Rabbit Feeding and Nutrition. Academic Press, Orlando, Florida, USA.

Cheeke, P.R.; Patton, N.M. and Templeton, G.S. (1982). Rabbit production. $5^{\text {th }}$ Ed., Interstate printers and publishers Inc. Danville, IL, USA.

Cuddeford, D. (1989). "Hydroponic Grass." In Practice 11(5): 211-214.

Duncan, D.B. (1955). Multiple Range and Multiple F- test. Biomertrics, 1:11.

Dung, D.D.; Godwin, I.R. and Nolan, J.V. (2010). Nutrient content and in sacco degradation of hydroponic barley sprouts grown using nutrient solution or tap water. J. Anim. Vet. Adv., 9 (18): 2432-2436.

El-Gogary, M.R.; Mansour, A.M. and El-Said, E.A. (2018). Blood biochemical and immunological responses to garlic oil administration in growing rabbits diet. Journal of Agricultural Science, 10 (1): 217-224.

Fayed, A.M. (2011). Comparative study and feed evaluation of sprouted barley grains on rice straw versus Tamarix mannifera on performance of growing Barki lambs in Sinai. Journal of American Science, 7: 954-961.

Fekete, S. (1987). The new Hungarian system for evaluation of feed energy. Proceeding of $1^{\text {st }}$ North American Rabbit Congress, October, 10-13, Portland- or, USA.

Gupta, J.J. (2014). Fodder production and livestock feeding management in Eastern India (Unpub.), ICAR Research Complex for Eastern Region, Patna.

Harcourt-Brown, F. (2002). Textbook of Rabbit Medicine, Butterworth, Heinemann, Oxford, UK.

Heinze, C. (2002). Rodent Reference Ranges. http:// cal. vet. upenn.edu/ projects/ssclinic/ refdesk/ rabbitrr. htm.

Hillier, R.J. and Perry, T.W. (1969). Effect of hydroponically produced oat grass on ration digestibility of cattle. Journal of Animal Science, 29: 783-785.

Ibrahim, A.; Fathia, Hoda, El-Hosseiny, M. and ElSayed, I.M. (2001): Effect of using sprouted barley by recycle process of agriculture residues on feeding value, rumen activity and some blood constituents of crossbred sheep. Egyptian J. Nutrition and Feeds, 4 (Special Issue): 265- 273. 
Jensen, H. and Malter, A. (1995). Protected agriculture a global review. World bank technical paper number $253.156 \mathrm{p}$.

Kumar, N.U.; Singh, S. and Verma, D.N. (1980). Effect of different levels of dietary protein and energy on growth of male buffalo calves. Ind. J. Anim.Sci., 51: 513.

MAFF (1975). Ministry of Agriculture, Fisheries and Food. Energy allowances and feeding systems for ruminants. Technical Bulletin, 33: London, H M50.

Mayer, A.M. and Poljakoff-Mayber, A. (1975). The Germination of Seeds, ( $2^{\text {nd }}$ edn). Pergamon Press, Toronto.

Mooney J. (2005). Growing cattle feed hydroponically. Meat and livestock Australia. $30 \mathrm{p}$.

Morgan, J.; Hunter, R.R. and O'Haire, R. (1992). Limiting factors in hydroponic barley grass production. $8^{\text {th }}$ International Congress on Soilless culture, Hunter's Rest, South Africa.

Morsy, A.T.; Abul S.F. and Emam, M.S.A (2013). Localized hydroponic green foragetechnology as a climate change adaptation under Egyptian condition. J. Agri. and Bio. Sci., 9 (6): 341- 350.

Naik, P.K.; Dhuri, R.B.; and Singh, N.P. (2011). Technology for production and feeding of hydroponics green fodder. Extension Folder No. 45/ 2011, ICAR Research Complex for Goa, Goa.

Naik, P.K.; Dhuri, R.B.; Karunakaran, M.; Swain, B.K. and Singh, N.P. (2013). Hydroponics technology for green fodder production. Indian Dairyman, March Issue, Pp.54-58.

Naik, P.K.; Dhuri, R.B.; Swain, B.K. and Singh, N.P. (2012). Nutrient changes with the growth of hydroponics fodder maize. Indian J. Anim. Nutr., 29: 161-163.

NRC (1977). Nutrients Requirements of Domestic Animals. Nutrients Requirements of Rabbits. $2^{\text {nd }}$ Edition. National Research Council, National Academy of Science. Washington, DC. USA.
Pagano Toscano, G.; Benatti, G. and Zoccarato, J. (1986). Comparision of crude fiber and the Van Soest detergent methods for fiber determination in rabbit feeds. J. Appl. Rabbit. Res., 9: 69.

Raeisi, Z.; Tahmasbi, R.; Dayani, O.; Ayatollahi Mehrgardi, A. and Tavassolian, I. (2018). Digestibility, microbial protein synthesis, rumen and blood parameters in sheep fed diets containing hydroponic barley fodder. J. Livestock Sci. and Technol., 6 (1): 09-17.

Reddy, G.V.; Reddy, M.R and Reddy, K.K. (1988). Nutrient utilization by milch cattle fed on rations containing artificially grown fodder". Indian J. Anim. Nutr., 5 (1): 19-22.

SAS Institute, I. (2003). SAS version 9.1.

Schiemane, R., Nehrina, K., Hofmann, L., Jentach, W. and Chudy, A. (1972). Energestische Futterbewertung und Energienormen, VEB, Deutscher Landwirtschafts Verlag, Berlin, p.72.

Shah, V.D., Makwana, M., and Sharma, S. (2011). Economics of production, processing and marketing of fodder crops in Gujarat. India Research Study No.144.

Shanti, H.; Omar, J.; Alwaheidi, IN.; Abdallah, J. and Dbadran, E. (2017). Effect of substituting hydroponic barley for a commercial feed on performance and blood metabolites of growing Baladi rabbits. J. New science, 39 (5): 2131-2135.

Shewry, P.R. (2007). Improving the protein content and composition of cereal grain. J. Cereal Sci., 46: 239250

Shipard, I. (2005). How can I grow and use sprouts as living food? $2^{\text {nd }}$ Edn. David Stewart, Hershey, PA., ISBN-13: 9780975825204, Pages: 136.

Sneath, R. and McIntosh, F. (2003). Review of hydroponic fodder production for beef cattle. Queensland Government, Department of primary Industries, Dalby, Quensland 84. McKeehen, pp: 54.

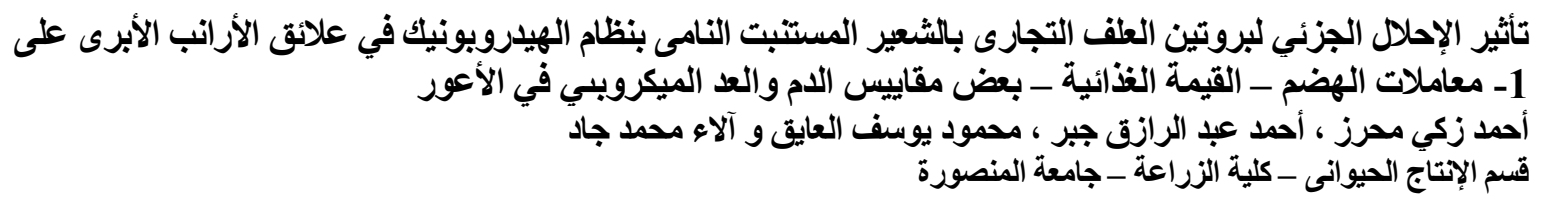

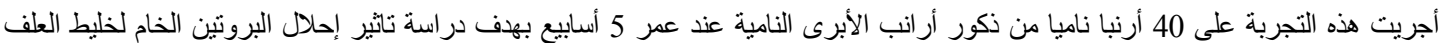

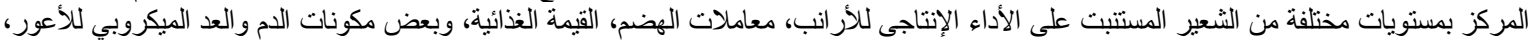

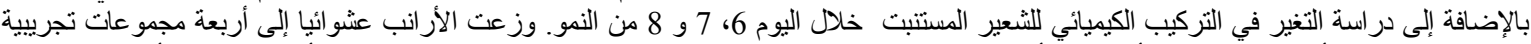

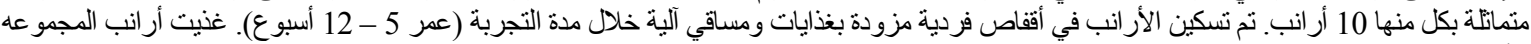

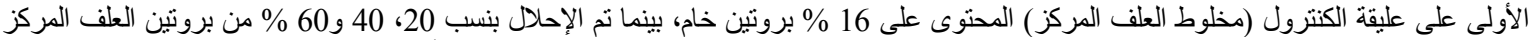

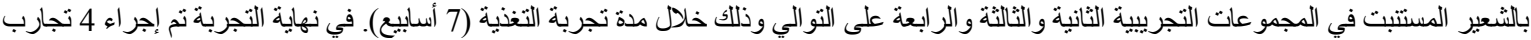

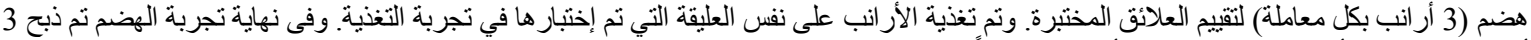

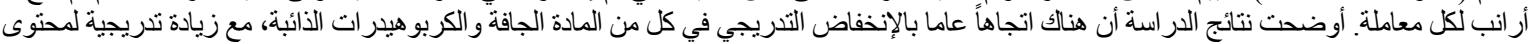

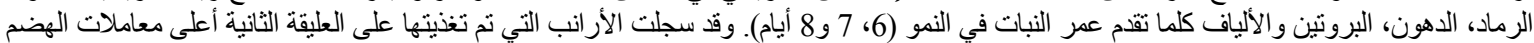

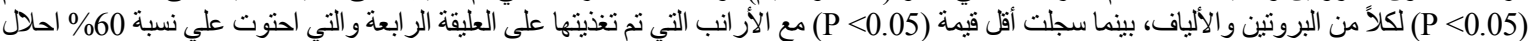

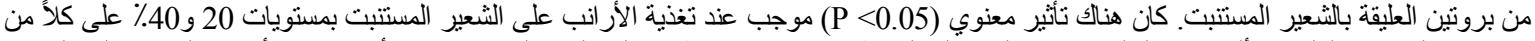

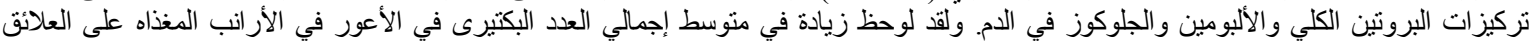

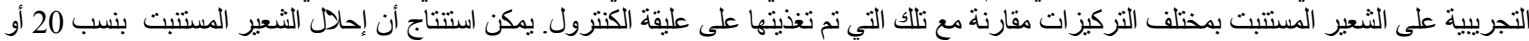

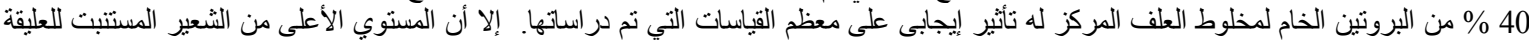
الر ابعة بنسبة 60\% من بروتين العلف المركز لا يوصى بإستخدامه لأنها تؤدى إلى انخفاض معظم قيم معاملات الهضم وكذلك القيم الغذائية. 